\title{
ANALISIS TINGKAT PARTISIPASI PESERTA PROGRAM CSR PEMBERDAYAAN EKONOMI PT ARUTMIN INDONESIA
}

\author{
Participation in Economic Empowerment CSR Programme by PT Arutmin Indonesia \\ Rahmawati ${ }^{*}$ dan Titik Sumarti
}

Departemen Sains Komunikasi dan Pengembangan Masyarakat, Fakultas Ekologi Manusia, IPB

*) Email : rahmawati@gmail.com

Diterima 25 Oktober 2011 / Disetujui 23 November 2011

\begin{abstract}
This research is focused on The Participation Level of Participant on Economic Empowerment CSR Programme. Participation is one of the most important aspect that is able to support the success of community development programme. The aims of this research were to 1) analyze level of will, capability, and opportunity from participant on economic empowerment programme; 2) analyze level of participation from participant on economic empowerment programme; 3) analyze relation between level of participation and level of will capability, and opportunity from participant on economic empowerment programme; 4) analyze relation between level of participation and level of economic capability from participant on economic empowerment programme. This research use quantitative approach with survay method. Respondent is participant on economic empowerment CSR programme totaly respondent is 60 persons. Respondent was chosen with purposive sampling. Processing of quantitative data using a Crosstab and Rank Spearman Correlation Test. Based on the Crosstab analysis results can be concluded that, on DPEM programme, there was no a correlation between level of will and level of participation, but there was a correlation between level of capability and level of opportunity with level of participation, and there was a correlation between level of participation and level of economic capability. On PPEM programme, there was no a correlation between level of capability and level of participation, there was a correlation between level of will and opportunity with level of participation, and there was no a correlation between level of participation and level of economic capability. Based on the results of research, there are a recomendations for Community Department, LPPM, and Dompet Dhuafa Republika: held a business development training for participant on DPEM programme, increas knowledge and skills of participant on PPEM programme, repairing pattern LPPM assistance to participant on DPEM programme, reintroduce DPEM programme to the community through directly socialization, increase participation of participant on DPEM programme through increase two-way communication between the company or LPPM with participant.
\end{abstract}

Keywords : economic empowerment CSR programme, participation, and economic capability.

\begin{abstract}
ABSTRAK
Penelitian ini difokuskan pada Tingkat Partisipasi Peserta Program CSR Ekonomi Pemberdayaan. Partisipasi merupakan salah satu aspek yang paling penting yang dapat mendukung keberhasilan program pengembangan masyarakat. Tujuan dari penelitian ini adalah untuk 1) menganalisis tingkat kemauan, kemampuan, dan kesempatan dari peserta pada program pemberdayaan ekonomi; 2) menganalisis tingkat partisipasi dari peserta pada program pemberdayaan ekonomi; 3) menganalisis hubungan antara tingkat partisipasi dan tingkat kemampuan, dan kesempatan dari peserta pada program pemberdayaan ekonomi; 4) menganalisis hubungan antara tingkat partisipasi dan tingkat kemampuan ekonomi dari peserta pada program pemberdayaan ekonomi. Penelitian ini menggunakan pendekatan kuantitatif dengan metode survei. Responden adalah peserta pada ekonomi program CSR pemberdayaan total responden adalah 60 orang. Responden dipilih secara purposive sampling. Pengolahan data kuantitatif menggunakan Crosstab dan Rank Spearman Uji Korelasi. Berdasarkan hasil analisis Crosstab dapat disimpulkan bahwa, pada program DPEM, tidak ada korelasi antara tingkat kemauan dan tingkat partisipasi, tapi ada hubungan antara tingkat kemampuan dan
\end{abstract}


tingkat kesempatan dengan tingkat partisipasi, dan ada korelasi antara tingkat partisipasi dan tingkat kemampuan ekonomi. Pada program PPEM, tidak ada korelasi antara tingkat kemampuan dan tingkat partisipasi, ada korelasi antara tingkat kemauan dan kesempatan dengan tingkat partisipasi, dan tidak ada hubungan antara tingkat partisipasi dan tingkat kemampuan ekonomi. Berdasarkan hasil penelitian, ada saran untuk Masyarakat Departemen, LPPM, dan Dompet Dhuafa Republika: mengadakan pelatihan pengembangan usaha bagi peserta pada program DPEM, pengetahuan semakin meningkat dan keterampilan peserta pada program PPEM, memperbaiki pola LPPM bantuan kepada peserta pada Program DPEM, memperkenalkan Program DPEM kepada masyarakat melalui sosialisasi langsung, meningkatkan partisipasi peserta pada program DPEM melalui peningkatan komunikasi dua arah antara perusahaan atau LPPM dengan peserta.

Kata kunci: pemberdayaan ekonomi program CSR, partisipasi, dan kemampuan ekonomi.

\section{PENDAHULUAN}

\section{Latar Belakang}

Perusahaan sebagai pelaku dunia usaha adalah salah satu dari pihak yang turut andil dalam menjalankan pemangunan di Indonesia. Kegiatan-kegiatan yang direncanakan oleh perusahaan umum melibatkan berbagai macam pihak, seperti pemerintah, masyarakat, pihak asing, dan lain sebagainya. Masyararakat yang berada di sekitar lokasi operasional perusahaan adalah salah satu pihak yang dapat mempengaruhi keberadaan dan keberlanjutan suatu perusahaan. Mereka adalah pihak yang paling merasakan dampak suatu kegiatan operasional perusahaan baik dari segi sosial ekonomi maupun lingkungan. Oleh karena itu, perusahaan sangat perlu menjaga keseimbangan dengan masyarakat khususnya yang berada di sekitar lokasi operasional perusahaan dalam rangka menjaga eksistensinya.

Keseimbangan dengan masyarakat dapat dijaga dengan melakukan Tanggung Jawab Sosial Perusahaan atau yang lebih dikenal dengan Corporate Social Responsibility (CSR). Penerapan CSR merupakan komitmen dunia usaha untuk terus bertindak etis, beroperasi secara legal, dan berkontribusi untuk peningkatan ekonomi, bersamaan dengan peningkatan kualitas hidup dari karyawan dan keluarganya sekaligus juga peningkatan kualitas komunitas lokal dan masyarakat secara luas (The World Bussiness Council for Sustainable Development (WBSCD) dalam Wibisono, 2007). Ambadar (2008) menyatakan bahwa pengembangan masyarakat adalah salah satu pendekatan yang harus menjadi prinsip utama bagi seluruh unit-unit kepemerintahan maupun pihak korporasi dalam menjalankan tugas dan fungsinya dalam memberikan pelayanan sosial. Hal ini disebabkan dalam pelaksanaan pengembangan masyarakat terdapat kolaborasi kepentingan bersama antara perusahaan dengan komunitas, adanya partisipasi, produktivitas, dan keberlanjutan. Ife (1995) mengemukakan beberapa prinsipprinsip Community Development yang salah satunya adalah partisipasi. Partisipasi semua pihak dalam program pengembangan masyarakat, dalam hal ini CSR, sangat menentukan keberhasilan program tersebut, terlebih partisipasi masyarakat sebagai sasaran program. Wibisono
(2007) menyatakan bahwa peran serta masyarakat merupakan salah satu kunci sukses dalam penerapan program CSR. Slamet (1994) mengemukakan bahwa terdapat faktor-faktor yang mendukung terciptanya partisipasi dalam masyarakat, yaitu adanya kemauan, kemampuan, dan kesempatan.

PT Arutmin Indonesia Tambang Senakin adalah salah satu perusahaan penghasil dan pengekspor batu bara terbesar di Indonesia. Perusahaan ini secara aktif melaksanakan kegiatan Corporate Social Resposibility (CSR) di daerah sekitar lokasi pertambangannya. Program pemberdayaan ekonomi masyarakat diantaranya adalah program Dana Pengembangan Ekonomi Masyarakat (DPEM) dan Program Pemberdayaan Ekonomi Masyarakat (PPEM). Dua program ini berupa pemberian dana bergulir serta pengembangan usaha kecil dan mandiri di berbagai bidang bagi masyarakat sekitar pertambangan. Penelitian ini bermaksud untuk meneliti lebih dalam tentang partisipasi pesertat dalam kedua program tersebut yang meliputi faktor-faktor yang mendorong terciptanya partisipasi, yaitu kemauan, kemampuan, dan kesempatan, tingkat partisipasinya di dalam program, serta ada tidaknya hubungan partisipasi mereka dalam program dengan kemampuan ekonominya, mengingat tujuan akhir dari program ini adalah untuk memperbaiki perekonomian masyarakat.

\section{Perumusan Masalah}

Berdasarkan latar belakang yang telah dipaparkan, berikut adalah rumusan masalah dari penelitian ini:

1. bagaimana tingkat kemauan, kemampuan, dan kesempatan peserta program pemberdayaan ekonomi?

2. bagaimana tingkat partisipasi peserta program pemberdayaan ekonomi dalam pelaksanaan program?

3. sejauhmana hubungan tingkat kemauan, kemampuan, dan kesempatan peserta program pemberdayaan ekonomi dengan tingkat partisipasinya dalam program tersebut?

4. sejauhmana hubungan tingkat partisipasi peserta program pemberdayaan ekonomi dengan tingkat kemampuan ekonominya? 


\section{Tujuan Penelitian}

Tujuan penelitian dirumuskan sebagai berikut: 1) mengidentifikasi tingkat kemauan, kemampuan, dan kesempatan peserta program pemberdayaan ekonomi; 2) mengidentifikasi tingkat partisipasi peserta program pemberdayaan ekonomi; 3) menganalisis hubungan antara tingkat kemauan, kemampuan, dan kesempatan peserta program pemberdayaan ekonomi dengan tingkat partisipasinya dalam program tersebut; dan 4) menganalisis hubungan antara tingkat partisipasi peserta program pemberdayaan ekonomi dengan tingkat kemampuan ekonominya.

\section{Kegunaan Penelitian}

Penelitian ini memiliki kegunaan sebagai berikut: 1) bagi akademisi, diharapkan tulisan ini dapat menjadi referensi dalam melakukan penelitian-penelitian terkait tanggung jawab sosial perusahaan; 2) bagi pemerintah, dapat dijadikan sebagai masukan dalam membuat kebijakan terkait dengan tanggung jawab sosial perusahaan; 3) bagi perusahaan, diharapkan hasil penelitian ini dapat menjadi masukan dalam merumuskan kebijakan dan program mengenai tanggung jawab sosial perusahaan di komunitas pedesaan; dan 4) bagi masyarakat, hasil penelitian ini mampu meningkatkan kesadaran dan pemahaman masyarakat mengenai penyelenggaraan tanggung jawab sosial perusahaan.

\section{PENDEKATAN TEORITIS}

\section{Tinjauan Pustaka}

\section{Corporate Social Responsibilty (CSR)}

\section{Definisi CSR}

The World Business Council for Suistainable Development (WBSCD) dalam Wibisono (2007) mendefinisikan CSR sebagai sebuah komitmen dunia usaha untuk terus menerus bertindak secara etis, beroperasi secara legal dan berkontribusi untuk peningkatan ekonomi, bersamaan dengan peningkatan kualitas hidup dari karyawan dan keluarganya sekaligus juga peningkatan kualitas komunitas lokal dan masyarakat secara lebih luas. Definisi tanggung jawab sosial yang digunakan Indonesia Business Links (IBL) adalah strategi bisnis yang melihat bahwa kepentingan bisnis jangka panjang dicapai dengan laba dan pertumbuhan, sejalan dengan kesejahteraan masyarakat, perlindungan lingkungan dan peningkatan hidup manusia (Sukada et al., 2007).

\section{Prinsip dan Ruang Lingkup CSR}

Konsep CSR melibatkan tanggung jawab kemitraan antara pemerintah, lembaga sumber daya masyarakat, juga komunitas setempat (lokal). Kemitraan ini, tidaklah bersifat pasif dan statis. Kemitraan ini merupakan tanggung jawab bersama secara sosial antar stakeholders (Budimanta et al., 2008). Adapun menurut Ambadar (2008) terdapat tiga tahapan yang harus dilakukan oleh suatu perusahaan dalam menerapkan program CSR yang sistematis dan kompleks, langkah atau tahapan yang dapat ditempuh adalah 1) melihat dan menilai kebutuhan (needs assessment) masyarakat sekitar; 2) membuat rencana aksi rangkap dengan anggaran, jadwal waktu, indikator untuk mengevaluasi dan sumber daya manusia yang ditunjuk untuk melakukannya; 3) monitoring, yang dapat dilakukan dengan survei maupun kunjungan langsung.

\section{Manfaat CSR}

Menurut Wibisono (2007), manfaat bagi perusahaan yang berupaya menerapkan CSR, yaitu dapat mempertahankan atau mendongkrak reputasi dan brand image perusahaan, layak mendapatkan social licence to operate, mereduksi risiko bisnis perusahaan, melebarkan akses sumber daya, membentangkan akses menuju market, mereduksi biaya, memperbaiki hubungan dengan stakeholders, memperbaiki hubungan dengan regulator, meningkatkan semangat dan produktivitas karyawan serta berpeluang mendapatkan penghargaan. Sementara itu, manfaat CSR bagi masyarakat menurut Ambadar (2008), yaitu dapat meningkatkan kualitas sumber daya manusia, kelembagaan, tabungan, konsumsi, dan investasi dari rumah tangga warga masyarakat.

\section{Pengembangan Masyarakat}

\section{Definisi dan Prinsip Pengembangan Masyarakat}

Menurut Ambadar (2008), pengembangan masyarakat adalah salah satu pendekatan yang harus menjadi prinsip utama bagi seluruh unit-unit kepemerintahan maupun pihak korporasi dalam menjalankan tugas dan fungsinya dalam memberikan pelayanan sosial. Peran serta masyarakat selama ini hanya dilihat dalam konteks yang sempit, yaitu manusia cukup dipandang sebagai tenaga kasar untuk mengurangi biaya pembangunan. Pada kondisi ini, partisipasi masyarakat hanya sebatas biaya pembangunan. Melihat kondisi ini, partisipasi masyarakat hanya sebatas pada implementasi atau penerapan program, masyarakat tidak dikembangkan dayanya menjadi kreatif dari dalam dirinya dan harus menerima keputusan yang sudah diambil "pihak luar". Akhirnya, partisipasi menjadi bentuk yang pasif dan tidak memiliki "kesadaran kritis" (Nasdian, 2006). Payne (1979) dalam Nasdian (2006) menjelaskan bahwa pemberdayaan ditujukan untuk membantu klien memperoleh daya (kuasa) untuk mengambil keputusan dan menentukan tindakan yang harus ia lakukan yang terkait dengan diri mereka, termasuk mengurangi efek hambatan pribadi dan sosial dalam melakukan tindakan. Hal ini dilakukan melalui peningkatan kemampuan dan rasa percaya diri untuk menggunakan daya yang dimiliki, antara lain melalui transfer daya dari lingkungannya.

\section{Partisipasi dalam Pengembangan Masyarakat}

Nasdian (2006) menjelaskan bahwa partisipasi adalah proses aktif, inisiatif diambil oleh warga komunitas sendiri, dibimbing oleh cara berfikir mereka sendiri, dengan menggunakan sarana dan proses (lembaga dan 
mekanisme) dimana mereka dapat menegaskan kontrol secara efektif. Arnstein (1969) seperti dikutip Chusnah (2008) menjelaskan ada delapan tangga partisipasi masyarakat, yang kemudian dikenal dengan tipologi Arnstein, yaitu sebagai berikut:

1. Manipulasi (manipulation), dengan mengatasnamakan partisipasi, masyarakat diikutkan sebagai "stempel karet" dalam badan penasihat. Tujuannya adalah untuk dipakai sebagai formalitas semata dan untuk dimanfaatkan dukungannya. Tingkat ini bukanlah tingkat partisipasi masyarakat yang murni, karena telah diselewengkan dan dipakai sebagai alat publikasi oleh pihak penguasa;

2. Terapi (therapy), pada tingkat therapy atau pengobatan ini, pemegang kekuasaan sama dengan ahli kesehatan jiwa. Mereka menganggap ketidakberdayaan sebagai penyakit mental dengan berpurapura mengikutsertakan masyarakat dalam suatu perencanaan. Mereka sebenarnya menganggap masyarakat sebagai sekelompok orang yang memerlukan pengobatan. Meskipun masyarakat dilibatkan dalam berbagai kegiatan, namun pada dasarnya kegiatan tersebut bertujuan untuk menghilangkan lukanya dan bukannya menemukan penyebab lukanya;

3. Pemberitahuan (informing), dengan memberi informasi kepada masyarakat tentang hak, tanggung jawab dan pilihan mereka merupakan langkah awal yang sangat penting dalam pelaksanaan partisipasi masyarakat. Namun seringkali pemberian informasi dari penguasa kepada masyarakat tersebut bersifat satu arah. Masyarakat tidak memiliki kesempatan untuk memberikan umpan balik dan tidak memiliki kekuatan untuk negosiasi. Apalagi ketika informasi disampaikan pada akhir perencanaan, masyarakat hanya memiliki sedikit kesempatan untuk mempengaruhi program. Komunikasi satu arah ini biasanya dengan menggunakan media pemberitaan, pamflet dan poster;

4. Konsultasi (consultation), meminta pendapat masyarakat merupakan suatu langkah logis menuju partisipasi penuh. Namun, konsultasi ini masih merupakan partisipasi semu karena tidak ada jaminan bahwa pendapat mereka akan diperhatikan. Cara yang sering digunakan dalam tingkat ini adalah jajak pendapat, pertemuan warga dan dengar pendapat. Jika pemegang kekuasaan membatasi usulan masyarakat, maka kegiatan tersebut hanyalah merupakan suatu partisipasi palsu. Masyarakat pada dasarnya hanya dianggap sebagai abstraksi statistik karena partisipasi hanya diukur dari frekuensi kehadiran dalam pertemuan, seberapa banyak brosur yang dibawa pulang dan juga dari seberapa banyak kuesioner dijawab. Dengan demikian, pemegang kekuasaan telah merasa memiliki bukti bahwa mereka telah mengikuti rangkaian pelibatan masyarakat;

5. Penentraman (placation), pada tingkat ini masyarakat sudah memiliki beberapa pengaruh meskipun dalam beberapa hal pengaruh tersebut tidak memiliki jaminan akan diperhatikan. Masyarakat memang diperbolehkan untuk memberikan masukan atau mengusulkan rencana tetapi pemegang kekuasaanlah yang berwenang untuk menentukan. Salah satu strateginya adalah dengan memilih masyarakat miskin yang layak untuk dimasukkan ke dalam suatu lembaga;

6. Kemitraan (partnership), pada tingkat ini, kekuasaan disalurkan melalui negosiasi antara pemegang kekuasaan dan masyarakat. Mereka sepakat untuk samasama memikul tanggung jawab dalam perencanaan dan pengambilan keputusan. Aturan di-tentukan dengan melalui mekanisme take and give, sehingga diharapkan tidak mengalami perubahan secara sepihak. Partnership dapat berjalan efektif bila dalam masyarakat ada kekuasaan yang terorganisir, pemimpinnya bertanggung jawab, masyarakat mampu membayar honor yang cukup bagi pemimpinnya serta adanya sumber dana untuk menyewa teknisi, pengacara dan organisator masyarakat. Dengan demikian, masyarakat benar-benar memiliki posisi tawarmenawar yang tinggi, sehingga akan mampu mempengaruhi suatu perencanaan;

7. Pendelegasian kekuasaan (delegated power), negosiasi antara masyarakat dengan pejabat pemerintah bisa mengakibatkan terjadinya dominasi kewenangan pada masyarakat terhadap rencana atau program tertentu. Pada tingkat ini masyarakat menduduki mayoritas kursi, sehingga memiliki kekuasaan dalam menentukan suatu keputusan. Selain itu, masyarakat juga memegang peranan penting dalam menjamin akuntabilitas program tersebut. Untuk mengatasi perbedaan, pemegang kekuasaan tidak perlu meresponnya tetapi dengan mengadakan proses tawar menawar;

8. Kontrol masyarakat (citizen control), pada tingkat ini, masyarakat menginginkan adanya jaminan bahwa kewenangan untuk mengatur program atau kelembagaan diberikan kepada mereka, bertanggung jawab penuh terhadap kebijakan dan aspek-aspek manajerial dan bisa mengadakan negosiasi apabila ada pihak ketiga akan mengadakan perubahan. Dengan demikian, masyarakat dapat berhubungan langsung dengan sumber-sumber dana untuk memperoleh bantuan atau pinjaman tanpa melewati pihak ketiga.

Berdasarkan kedelapan tangga tersebut, Arnstein mengelompokkannya lagi menjadi tiga tingkat, yaitu: a) tidak ada partsisipasi (nonparticipation); b) tokensime atau sekedar justifikasi agar masyarakat mengiyakan (degree of tokenism); dan c) tingkatan kekuasaan ada di masyarakat (degree of citizen power).

\section{Faktor-faktor yang Mendukung Partisipasi}

Slamet (2003) mengemukakan bahwa partisipasi masyarakat dalam proses pembangunan akan terwujud sebagai suatu kejadian nyata apabila terpenuhi faktor-faktor yang mendukungnya, yaitu a) adanya kesempatan, yaitu adanya suasana atau kondisi lingkungan yang disadari oleh orang tersebut bahwa dia berpeluang untuk berpartisipasi; b) 
adanya kemauan, yaitu adanya sesuatu yang mendorong atau menumbuhkan minat dan sikap mereka untuk termotivasi berpartisipasi, misalnya berupa manfaat yang dapat dirasakan atas partisipasinya tersebut; dan c) adanya kemampuan, yaitu adanya kesadaran atau keyakinan pada dirinya bahwa dia mempunyai ke-mampuan untuk berpartisipasi, bisa berupa pikiran, tenaga, waktu, atau sarana dan material lainnya.

Lugiarti (2004) mengemukakan bahwa kemauan ditentukan oleh faktor yang bersifat psikologis individu, seperti motif, harapan, kebutuhan, dan imbalan. Dorongan seseorang melakukan suatu kegiatan untuk mencapai suatu tujuan sangat tergantung pada besarnya harapan akan tercapainya suatu tujuan tersebut. Harapan mendapatkan manfaat atau imbalan tertentu, terutama dalam kaitannya dengan pemenuhan kebutuhan dasar hidupnya, merupakan sumber motivasi bagi seseorang untuk berperan serta dalam kegiatan-kegiatan pembangunan. Makin banyak manfaat yang diduga akan diperoleh dalam kegiatan pembangunan, maka semakin kuat keterlibatan seseorang dalam kegiatan pembangunan. Di samping itu, tingkat penguasaan informasi merupakan faktor yang sangat menentukan timbulnya kemauan seseorang untuk berpartisipasi dalam pembangunan. Kesempatan masyarakat untuk berpartisipasi dalam pembangunan dipengaruhi oleh faktor kesediaan sarana dan prasarana fisik, kelembagaan (formal dan lokal), kepemimpinan, pengaturan dan pelayanan yang dilakukan pemerintah desa. Lugiarti (2004) dalam tesisnya mencantumkan pendidikan, pengalaman, dan modal sebagai bagian dari faktor kemauan.

\section{Kemampuan Ekonomi}

Beragam definisi pemberdayaan menjelaskan bahwa pemberdayaan adalah sebuah proses dan tujuan. Sebagai proses, pemberdayaan adalah serangkaian kegiatan untuk memperkuat kekuasaan atau keberdayaan kelompok lemah dalam masyarakat, termasuk individu-individu yang mengalami masalah kemiskinan. Sebagai tujuan, maka pemberdayaan menunjuk pada keadaan atau hasil yang ingin dicapai oleh sebuah perubahan sosial, yaitu masyarakat miskin yang berdaya, memiliki kekuasaan atau mempunyai pengetahuan dan kemampuan dalam memenuhi kebutuhan hidupnya baik yang bersifat fisik, ekonomi, maupun sosial, seperti memiliki kepercayaan diri, mampu menyampaikan aspirasi, mempunyai mata pencaharian, berpartisipasi dalam kegiatan sosial, dan mandiri dalam melaksanakan tugas-tugas kehidupannya. Pengertian pemberdayaan sebagai tujuan seringkali digunakan sebagai indikator keberhasilan pemberdayaan sebagai sebuah proses. Keberhasilan pemberdayaan keluarga miskin dapat dilihat dari keberdayaan mereka yang menyangkut kemampuan ekonomi, kemampuan mengakses manfaat kesejahteraan, dan kemampuan kultural dan politis jenis. Ketiga aspek tersebut dikaitkan dengan empat dimensi kekuasaan, yaitu "kekuasaan di dalam" (power within), "kekuasaan untuk" (power to), "kekuasaan atas" (power over), dan "kekuasaan dengan" (power with).

\section{Kerangka Pemikiran}

Berpartisipasi dalam suatu program berarti berperan serta dalam program tersebut serta turut menikmati hasilnya. Adapun hasil yang diterimanya sangat tergantung pada seberapa besar sumbangannya dalam program, yang tergantung pada kemauan, kemampuan, dan kesempatan yang diperolehnya untuk berpartisipasi. Terdapat tiga faktor utama untuk dapat terlibat dalam program, yaitu 1) adanya kemauan; 2) adanya kemampuan; dan 3) adanya kesempatan untuk berpartisipasi. Kemauan dan kemampuan merupakan potensi yang dimiliki oleh pelaku secara individu ataupun kelompok. Sedangkan kesempatan lebih dipengaruhi oleh situasi atau lingkungan di luar diri pelaku.

Tingkat kemauan ditentukan oleh faktor yang bersifat psikologis individu, seperti harapan akan imbalan atau manfaat dari program dan motivasi terlibat dalam program. Dorongan seseorang melakukan suatu kegiatan untuk mencapai suatu tujuan sangat tergantung pada besarnya harapan akan tercapainya tujuan tersebut. Harapan mendapatkan manfaat atau imbalan tertentu, terutama dalam kaitannya dengan pemenuhan kebutuhan dasar hidupnya, merupakan sumber motivasi bagi seseorang untuk berperan serta dalam kegiatan-kegiatan pembangunan. Di samping itu, tingkat penguasaan informasi merupakan faktor yang sangat menentukan timbulnya kemauan seseorang untuk berpartisipasi (Lugiarti, 2004). Tingkat kemampuan seseorang berpartisipasi dalam suatu program ditentukan oleh tingkat pendidikan dan pengalamannya, sedangkan tingkat kesempatan untuk berpartisipasi dalam program ditentukan oleh pihak luar, dalam hal ini adalah penyelenggara program, yaitu sejauh mana penyelenggara memberikan ruang kepada sasaran program untuk berpartisipasi. Dalam hal ini adalah keterdedahan informasi dan tingkat pendampingan yang diterima peserta program dari penyelenggara program.

Faktor-faktor yang telah disebutkan merupakan faktorfaktor yang berkaitan dengan tingkat partisipasi masyarakat dalam sebuah program atau proses pembangunan lainnya. Partisipasi masyarakat akan menentukan keberhasilan suatu program. Beranjak dari pentingnya partisipasi masyarakat, maka penulis memiliki hipotesis umum dalam penelitiannya bahwa seseorang yang memiliki tingkat kemauan, kemampuan, dan kesempatan tinggi memiliki kecenderungan tingkat partisipasi tinggi dalam program pemberdayaan ekonomi masyarakat, dan seseorang yang memiliki tingkat partisipasi tinggi dalam program pemberdayaan ekonomi masyarakat memiliki kecenderungan tingkat kemampuan ekonomi tinggi. 


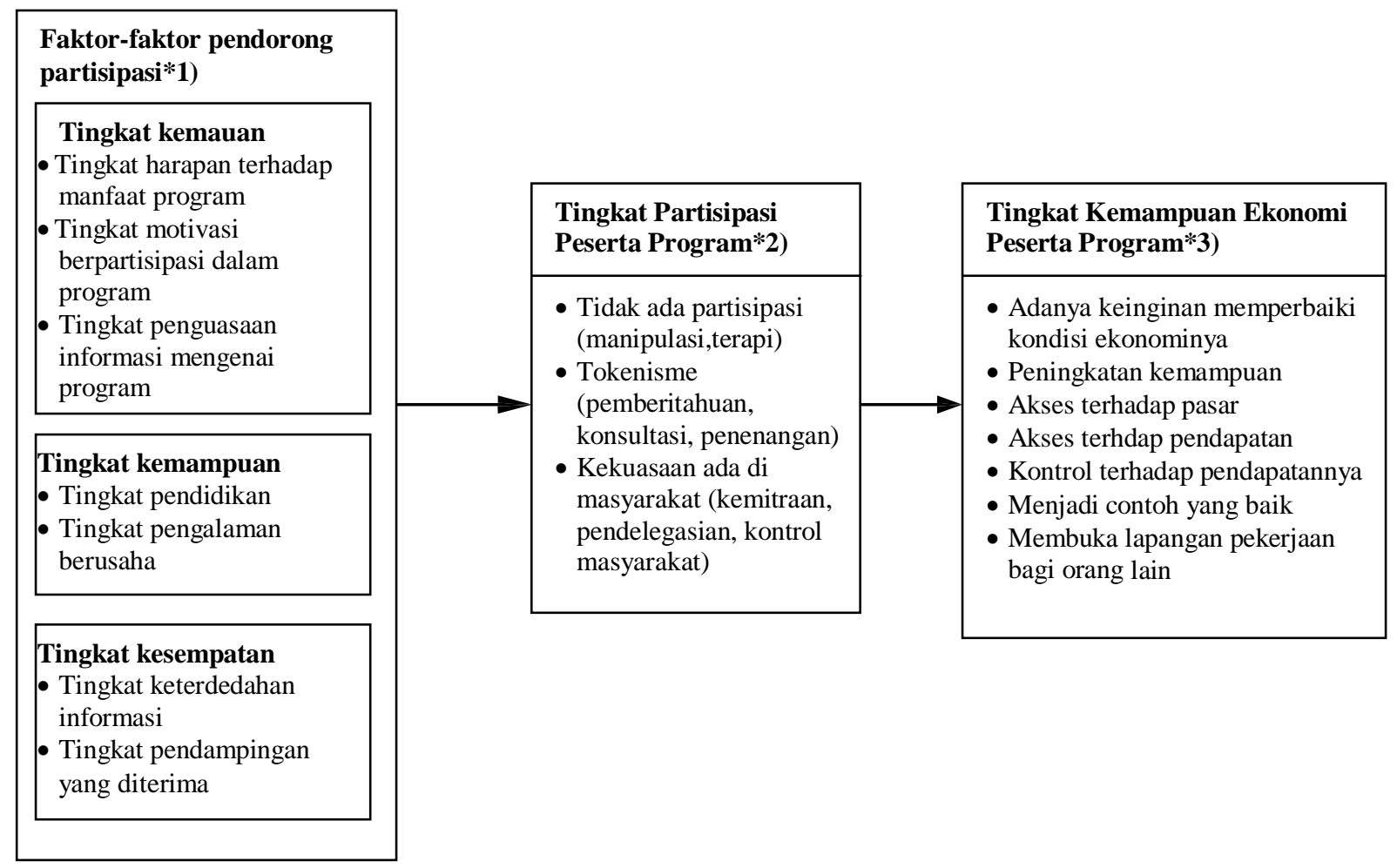

Keterangan:

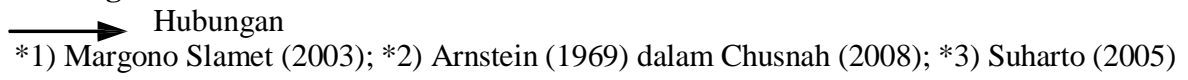

Gambar 1. Kerangka Pemikiran Analisis Partisipasi Peserta Program CSR Pemberdayaan Ekonomi PT Arutmin Indonesia

\section{Hipotesis Penelitian}

Hipotesis dari penelitian ini adalah:

1. terdapat hubungan antara tingkat kemauan peserta program pemberdayaan ekonomi dengan tingkat partisipasinya;

2. terdapat hubungan antara tingkat kemampuan peserta program pemberdayaan ekonomi dengan tingkat partisipasinya;

3. terdapat hubungan antara tingkat kesempatan peserta program dengan tingkat partisipasinya;

4. terdapat hubungan antara tingkat partisipasi peserta program pemberdayaan ekonomi dengan tingkat kemampuan ekonominya.

\section{PENDEKATAN LAPANGAN}

\section{Metode Penelitian}

Penelitian ini menggunakan pendekatan kuantitatif dengan menggunakan metode survei, yaitu dengan menggunakan pertanyaan terstruktur atau sistematis yang sama kepada banyak orang (kuesioner), untuk kemudian seluruh jawaban yang diperoleh peneliti dicatat, diolah, dan dianalisis.

\section{Lokasi dan Waktu Penelitian}

Penelitian dilaksanakan di 15 desa binaan PT Arutmin Indonesia Tambang Senakin yang menerima program DPEM yang terhitung sejak tahun 2007 dan PPEM Dompet Dhuafa Republika tahun 2010, yaitu Desa Sebuli, Tanah Rata, Senakin Seberang, Senakin Pasar, Sungai Punggawa, Tanjung Selayar, Geronggang, Tamiang Bakung, Tebing Tinggi, Sungai Seluang, Pudi Pasar, Gunung Calang, Sekandis, Papaan, dan Gunung Batu Besar. Penelitian berlangsung pada bulan April sampai dengan Mei 2011.

\section{Teknik Penentuan Responden}

Populasi dari penelitian ini adalah masyarakat yang berpartisipasi dalam program pemberdayaan ekonomi PT Arutmin Indonesia Tambang Senakin, yaitu sebanyak 174 orang. Total populasi tersebut merupakan gabungan dari jumlah dua program, yaitu program DPEM dan PPEM. Masyarakat yang berpartisipasi dalam program DPEM sejak tahun 2007 sampai 2010 sebanyak 61 orang dan masyarakat yang berpartisipasi dalam PPEM pada tahun 2010 sebanyak 113 orang. Penentuan responden dalam penelitian ini dilakukan dengan secara sengaja atau purposive sampling. Jumlah responden dalam penelitian ini adalah 60 yang terdiri dari 30 responden program DPEM dan 30 responden PPEM. 
Pemilihan informan dilakukan dengan teknik snowball sampling atau teknik bola salju. Informan dalam penelitian ini adalah Superintendent Community Department yang juga merangkap sebagai ketua LPPM, Community Development Officer (CDO), tim pendamping LPPM, tim pendamping Dompet Dhuafa Republika, Kepala Desa, Sekretaris Desa, dan beberapa peserta program pemberdayaan ekonomi PT Arutmin Indonesia Tambang Senakin. Unit analisis dalam penelitian ini adalah individu.

\section{Teknik Pengumpulan Data}

Jenis data yang akan digunakan dalam penelitian ini adalah data primer dan sekunder. Data primer diperoleh melalui wawancara terstruktur dan menggunakan kuesioner yang disebarluaskan, kemudian diisi oleh responden dan panduan wawancara untuk informan. Data yang didapat dari penelitian survei ini mencakup karakteristik individu, faktor-faktor yang mempengaruhi partisipasi responden, yaitu kemauan, kemampuan, dan kesempatan, tingkat partisipasi, serta tingkat kemampuan ekonomi masyarakat peserta program pemberdayaan ekonomi. Penelitian ini menggunakan wawancara mendalam (in depth interview) kepada informan dengan menggunakan panduan pertanyaan. Observasi dilakukan sebagai metode pengumpulan data untuk mengamati perkembangan usaha mandiri yang didirikan atau dikembangkan dari hasil partisipasi dengan program pemberdayaan ekonomi.

Data sekunder yang digunakan dalam penelitian ini meliputi data milik Community Development PT Arutmin Indonesia Tambang Senakin dan Dompet Dhuafa Republika. Data tersebut meliputi data peserta program DPEM dan PPEM, data analisis usaha DPEM, data karakteristik usaha DPEM dan PPEM, perkembangan usaha DPEM dan PPEM, serta laporan triwulan Dompet Dhuafa Republika kepada PT Arutmin Indonesia Tambang Senakin.

\section{Teknik Pengolahan dan Analisis Data}

Pengolahan data kuantitatif dilakukan dengan Tabulasi Silang didukung dengan Uji Korelasi Rank Spearman untuk mengukur tingkat kemauan, tingkat kemampuan dan kesempatan dan hubungannya dengan tingkat partisipasi, serta mengukur hubungan antara tingkat partisipasi dengan tingkat kemampuan ekonomi. Tabel frekuensi digunakan untuk mendeskripsikan karakteristik sosial ekonomi masyarakat, tingkat kemauan, kemampuan, kesempatan, tingkat partisipasi dan tingkat kemampuan ekonomi. Pengujian ini menggunakan program komputer SPSS 16.0 for Windows dan Microsoft Excel 2007. Data kualitatif berupa hasil wawancara dengan responden dan informan dianalisis untuk mendukung data kuantitatif.

\section{GAMBARAN PROGRAM CSR PT ARUTMIN}

\section{Community Department PT Arutmin Indonesia Tambang Senakin}

\section{Ruang Lingkup CSR Community Department}

PT Arutmin Indonesia adalah salah satu perusahaan penghasil dan pengekspor batu bara terbesar di Indonesia yang berlokasi di Kalimantan Selatan. PT Arutmin Tambang Senakin adalah salah satu tambang PT Arutmin Indonesia yang wilayah operasionalnya berada di semenanjung Senakin, Kabupaten Kotabaru. PT Arutmin Tambang Senakin merupakan salah satu perusahaan yang aktif melaksanakan kegiatan tanggung jawab sosial perusahaan atau Corporate Social Responsibility (CSR). Kegiatan CSR perusahaan ini dilaksanakan oleh satu departemen khusus, yaitu Community department.

Kegiatan CSR yang dilaksanaan Community Relation meliputi pembangunan infrastruktur untuk masyarakat sekitar tambang, yaitu perbaikan jalan desa, sarana air bersih, pemasangan listrik desa, dan pembangunan sarana pendidikan. Kegiatan CSR yang dilaksanakan oleh Community Development, meliputi bidang pendidikan, kesehatan, dan pengembangan ekonomi. Program di bidang pendidikan meliputi pemberian beasiswa untuk pelajar SD, SMP, SMA dan mahasiswa, kegiatan magang dan penelitian di perusahaan, lomba cerdas cermat, pelatihan pendidikan, bantuan fasilitas pendidikan, serta mining tour atau tur tambang untuk pelajar dan mahasiswa. Program di bidang kesehatan antara lain bakti sosial operasi katarak, luka bakar, dan bibir sumbing; donor darah; bantuan fasilitas kesehatan; serta pendidikan untuk bidan. Program di bidang pengembangan ekonomi meliputi budidaya karet klonal, pembibitan karet, tebar bibit karet klonal, Pusat Pelatihan dan Pengembangan Terpadu atau P4T Dahlia (demplot perkebunan, peternakan, pengembangan pupuk organik dan biogas), Lembaga Pengembangan Perekonomian Masyarakat (LPPM), serta pemberdayaan ekonomi masyarakat kerja sama dengan Dompet Dhuafa Republika.

Sasaran kegiatan Community Department adalah masyarakat desa di sekitar pertambangan. PT Arutmin Tambang Senakin memiliki 29 desa binaan yang tersebar di empat kecamatan di Kabupaten Kotabaru, yaitu Kecamatan Kelumpang Utara, Kelumpang Tengah, Pamukan Selatan, dan Sampanahan. Desa binaan terbagi dalam tiga ring yang diukur berdasarkan jarak desa dari lokasi operasional pertambangan.

\section{Tahapan CSR PT Arutmin Indonesia Tambang Senakin}

Pelaksanaan tanggung jawab sosial perusahaan atau Corporate Social Responsibility (CSR) PT Arutmin Indonesia Tambang Senakin sudah dimulai sejak kegiatan operasional pertambangan dilaksanakan. Namun kegiatan CSR yang dilaksanakan untuk masyarakat sekitar perusahaan umumnya masih bersifat charity. Pada tahun 
2002 terjadi demonstrasi yang dilakukan oleh masyarakat sekitar tambang. Masyarakat menuntut perusahaan untuk lebih memperhatikan kesejahteraan masyarakat sekitar lokasi pertambangan. Menjawab tuntutan masyarakat, di tahun yang sama perusahaan membentuk Lembaga Pengembangan Perekonomian Masyarakat (LPPM). LPPM melalui program Dana Pengembangan Ekonomi Masyarakat (DPEM) menyalurkan bantuan berupa dana bergulir untuk pengembangan ekonomi masyarakat ke setiap desa melalui Lembaga Pemberdayaan Masyarakat Desa (LPMD) di setiap desa. Sampai saat ini pelaksanaan program DPEM yang dilaksanakan oleh LPPM belum mencapai target yang diharapkan karena masyarakat penerima program DPEM sebagian besar tidak melanjutkan usahanya dan tidak melunasi pinjaman dana bergulir. Perusahaan menganalisis faktor penyebab kegagalan program tersebut karena masyarakat menafsirkan dana bergulir yang disalurkan melalui LPPM adalah dana hibah sehingga merasa tidak perlu untuk mengembalikannya.

Tahun 2010 perusahaan bekerja sama dengan Dompet Dhuafa Republika (DD) untuk mengembangkan perekonomian masyarakat di sekitar wilayah operasional pertambangan melalui program Pengembangan Pemberdayaan Ekonomi Masyarakat (PPEM). Pelaksanaan PPEM berupa pengguliran dana dengan sistem syariah, pendampingan intensif dan pembentukan lembaga keuangan mikro yang akan dikelola masyarakat. Masyarakat penerima PPEM tidak diberi tahu bahwa program ini berasal dari PT Arutmin Indonesia Tambang Senakin. Harapannya masyarakat dapat lebih bertanggung jawab dalam mengelola dana pinjaman yang diberikan oleh DD. Kerja sama PT Arutmin Tambang Senakin dan DD dalam upaya mengembangkan perekonomian masyarakat sekitar merupakan bentuk keseriusan perusahaan untuk melakukan kegiatan pengembangan masyarakat yang berkelanjutan. Sejarah perkembangan CSR PT Arutmin menunjukkan adanya perubahan pendekatan yang dilakukan. Pada awalnya program CSR PT Arutmin masih berupa charity. Namun, pada saat ini program CSR perusahaan sudah cenderung kepada Community Development, yaitu dengan adanya PPEM.

Lembaga Pengembangan Perekonomian Masyarakat (LPPM)

\section{Sejarah LPPM}

Pada tahun 2002 PT Arutmin Indonesia Tambang Senakin mendirikan sebuah lembaga yang bertujuan untuk memberdayakan perekonomian masyarakat bernama Lembaga Pengembangan Perekonomian Masyarakat (LPPM). LPPM memiliki konsultan yang didatangkan dari Satui, dan dua orang pendamping lapang. Pada saat itu pendamping memberikan bimbingan ke KUM binaan di desa-desa dengan melakukan verifikasi usaha, memberikan motivasi, pelatihan usaha, dan pelatihan pembukuan Dalam perjalanannya, dana yang dikucurkan LPPM melalui LPMD tidak seluruhnya dapat dikelola dengan baik. Banyak KUM yang usahanya terhenti dan tidak mengembalikan dana pinjaman kepada LPMD. Beberapa penyebabnya, seperti tidak tersedianya pasar hasil produksi karena jalan penghubung yang kondisinya buruk dan menyulitkan penjualan hasil usaha, mental sumber daya manusia, seperti anggapan bahwa dana yang dikucurkan LPPM dianggap dana hibah dan tidak perlu dikembalikan, dan teknis pelaksanaan program yang kurang terencana, seperti pendamping yang hanya terfokus mengembangkan usaha tanpa memberikan saran mengenai pasar untuk hasil produksi usaha masyarakat. Dalam hal ini pendamping lapang hanya menjalankan tugas sesuai instruksi dari ketua LPPM, yaitu memberikan bantuan dana kepada masyarakat. Sifat program DPEM diakui oleh pendamping lapang memang masih bersifat charity dan dilakukan sebatas meredam konflik dengan masyarakat untuk mengamankan kegiatan operasional pertambangan. Tahun 2005 pemberian dana bergulir melalui LPMD dihentikan, dan pengelolaan dana bergulir diambil alih oleh LPPM dengan menyalurkannya secara langsung kepada masyarakat yang ingin memiliki usaha dan membutuhkan bantuan modal. Mulai saat itu program DPEM hanya sebatas mengarahkan masyarakat yang memiliki tekad untuk berusaha.

\section{Kelembangaan LPPM}

Posisi LPPM berada langsung di bawah Community Department dan diketuai oleh Community Superintendent. LPPM memiliki dua orang pendamping lapang untuk seluruh desa binaan. Misi LPPM adalah meningkatkan ekonomi masyarakat sekitar tambang bidang usaha ekonomi produktif melalui program Dana Pengembangan Ekonomi Masyarakat (DPEM). Usaha yang mandiri merupakan hasil akhir yang ingin dicapai lembaga ini. Diharapkan setelah aktivitas pertambangan selesai kegiatan usaha akan tetap berjalan. LPPM belum memiliki target kerja yang terencana dalam melaksanakan tugasnya. Sasaran utama dari kegiatan LPPM adalah masyarakat sekitar tambang yang keberadaannya dirasa perusahaan berpotensi mengganggu kegiatan operasional tambang. Mereka adalah masyarakat yang kontra dengan adanya kegiatan penambangan batubara di daerahnya. LPPM berusaha merangkul mereka dengan memberikan apa yang mereka inginkan demi mencegah konflik muncul kembali. Namun selain itu, LPPM tetap menjalankan tugasnya untuk membantu masyarakat yang ingin berusaha dan membutuhkan bantuan.

\section{Program Dana Pengembangan Ekonomi Masyarakat (DPEM)}

Dana Pengembangan Ekonomi Masyarakat (DPEM) adalah program berbentuk pemberian dana bergulir untuk usaha berkelompok yang dinamakan Kelompok Usaha Mandiri (KUM). Bidang usaha yang dapat diajukan meliputi pertanian, peternakan, perikanan, perkebunan, perdagangan dan jasa atau keterampilan. DPEM adalah program yang dilaksanakan oleh LPPM PT Arutmin Indonesia Tambang Senakin dalam rangka mengembang- 
kan perekonomian masyarakat sekitar tambang yang berada dalam lingkup desa binaan perusahaan.

Tahun 2002, awal program DPEM dilaksanakan, dana bergulir disalurkan kepada Lembaga Pemberdayaan Masyarakat Desa (LPMD) di 19 desa binaan PT Arutmin Indonesia Tambang Senakin. Masing-masing LPMD di tiap desa menerima pengguliran dana Rp12.500.000,00 setiap empat bulan sekali. Dana tersebut disalurkan kepada KUM yang ada di desa berupa dana pinjaman yang pengembaliannya diangsur satu bulan sekali. Dana tersebut harus diputar atau digulirkan oleh LPMD kepada KUM lainnya. Tahun 2005 sistem kucuran dana bergulir melalui LKMD dihentikan. LPPM memutuskan mengelola sendiri dana bergulir dan hanya akan diperuntukan bagi KUM yang benar-benar berkeinginan memiliki atau mengembangkan usaha. Masyarakat yang menginginkan bantuan modal usaha dari program DPEM tidak lagi mengajukannya melalui LKMD, melainkan langsung mengajukan kepada pendamping lapang, Communnity Development Officer (CDO) atau Community Superintendent selaku ketua LPPM. Sesekali CDO dan pendamping lapang LPPM mengadakan sosialisasi program DPEM ke desa-desa. Masyarakat yang ingin mengajukan permohonan pinjaman DPEM harus tergabung dalam bentuk Kelompok Usaha Mandiri (KUM) yang terdiri dari tiga sampai lima orang anggota. KUM mengajukan proposal kepada pendamping lapang, CDO, atau Community Superintendent. Selanjutnya, LPPM akan melakukan analisa usaha dari proposal yang diajukan dan melakukan peninjauan untuk menilai kelayakan calon peserta program DPEM. Kegiatan pendampingan yang dilaksanakan berupa kunjungan pendamping lapang sebulan sekali untuk mengambil angsuran dari KUM. Sesekali pendamping memberikan saran mengenai usaha.

\section{Dompet Dhuafa Republika}

\section{Kelembagaan Tim Pendamping Dompet Dhuafa Republika}

PT Arutmin Indonesia Tambang Senakin adalah salah satu perusahaan yang melakukan kerja sama dengan DD dalam rangka pemberdayaan masyarakat sekitar perusahaan. Program kerja sama tersebut bernama Program Pemberdayaan Ekonomi Masyarakat Sekitar Pertambangan Senakin atau PPEM. Program ini mulai dijalankan pada Februari 2010.

Perusahaan mempercayakan sebagian dana program CSR tahun 2010 kepada DD dalam pendayagunaannya melalui PPEM bagi komunitas pelaku usaha mikro dan kecil berbasis kelompok. Pelaksanaan PPEM di lapangan sepenuhnya dilaksanakan oleh tim pendamping lapang DD. Tim pendamping diharuskan melaporkan kegiatan pemberdayaan secara berkala kepada perusahaan dan melakukan kegiatan evaluasi program bersama dengan perusahaan.
Tabel 1. Profil Program Pemberdayaan Ekonomi Masyarakat (PPEM) Sumber: Laporan Triwulan Dompet Dhuafa Republika (2011)

\begin{tabular}{ll}
\hline \multicolumn{1}{c}{ Deskripsi } & \multicolumn{1}{c}{ Keterangan } \\
\hline Nama & Pemberdayaan Ekonomi Masyarakat Sekitar \\
program & Pertambangan Senakin \\
& "Pembentukan Lembaga Keuangan Mikro yang \\
& Didukung Aktifitas Usaha Mikro dan Kecil \\
& Berbasis Kelompok"
\end{tabular}

Tujuan Meningkatnya kesejahteraan masyarakat di sekitar wilayah kerja perusahaan

Output - Terbentuknya satu lembaga keuangan mikro (LKM) yang sehat, mandiri dan berkelanjutan;

- Terbentuknya 2 unit Kelompok Usaha Mandiri (KUM) di tiap desa sasaran;

- Terbentuknya jaringan pemasaran permanen atas barang dan jasa yang diproduksi oleh KUM di tiap desa sasaran

Target area Enam desa di sekitar ring I PT. Arutmin Indonesia Tambang Senakin (Desa Geronggang, Desa Sungai Seluang, Desa Pudi, Desa Sebuli, Desa Senakin Seberang, Desa Tanah Rata)

Batas waktu 12 bulan ( satu tahun)

Target Minimal dua kelompok Usaha Mandiri (KUM) penumbuhan di setiap Desa Binaan

kelompok, Satu Lembaga Lokal (LL) berbadan hukum lembaga koperasi

usaha

Aktivitas 1. Pendampingan kelompok

2. Pembiayaan usaha produktif

3. Pembentukan kelompok usaha mandiri

4. Penumbuhan kader dan kelembagaan lokal

5. Monitoring dan evaluasi

6. Peningkatan kapasitas SDM dan Usaha

7. Perluasan jaringan pemasaran

8. Menjalin kerja sama lintas pelaku

\section{Program Pemberdayaan Ekonomi Masyarakat} (PPEM)

Program Pemberdayaan Ekonomi Masyarakat Sekitar Pertambangan Senakin atau PPEM adalah program pemberdayaan masyarakat PT Arutmin Indonesia Tambang Senakin kerja sama dengan Dompet Dhuafa Republika (DD). Pembiayaan KUM dalam PPEM meng-gunakan sistem syariah. Sistem ini cukup sesuai diterapkan di masyarakat sekitar pertambangan Senakin yang mayoritas beragama Islam dan nuansa keagama-annya masih kental. Akad syariah yang diterapkan pada program ini, yaitu Murobahah (Jual Beli), Qodrul Hasan (Pembiayaan Kebajikan), dan Mudarobah (Bagi Hasil). PPEM juga telah membentuk Koperasi Rakat Bersama yang membawahi Unit Usaha Induk di setiap desa dan Lembaga Keuangan Mikro Syariah (LKMS) Rakat Bersama. LKMS Rakat Bersama dibentuk sebagai wadah simpanan dan pinjam masyarakat dengan pola syariah. LKMS Rakat Bersama dikelola oleh masyarakat setempat 
namun masih tetap dalam pembinaan tim pendamping PPEM.

\section{HASIL PENELITIAN}

\section{Tingkat Kemauan, Kemampuan, dan Kesempatan Peserta Program}

Tingkat kemauan peserta program DPEM dan PPEM cenderung relatif tinggi, artinya keinginan peserta untuk berpartisipasi dalam program pemberdayaan ekonomi relatif tinggi. Berdasarkan hal tersebut, terlihat bahwa peserta menaruh harapan besar kepada program DPEM dan PPEM. Umumnya peserta berharap mendapatkan pelatihan dari penyelenggara program, dapat memiliki usaha yang berkelanjutan dan memperoleh pendapatan dari usahanya, memperbaiki kondisi perekonomiannya dengan turut serta dalam program pemberdayaan ekonomi. Peserta PPEM relatif memiliki tingkat kemampuan rendah lebih banyak dibandingkan peserta program DPEM, atau dengan kata lain peserta program DPEM cenderung memiliki tingkat kemampuan yang lebih tinggi dibandingkan peserta PPEM. Tingkat kesempatan peserta PPEM cenderung lebih tinggi dibandingkan tingkat kesempatan peserta program DPEM. Hal ini disebabkan peserta PPEM memiliki tingkat keterdedahan informasi dan tingkat pendampingan yang tinggi dari tim pendamping DD, sedangkan responden program DPEM umumnya cenderung memiliki tingkat keterdedahan informasi sedang dan tingkat pendampingan yang rendah dari LPPM sehingga tingkat kesempatannya pun rendah.

\section{Tingkat Partisipasi Peserta Program}

Tingkat partisipasi peserta program DPEM cenderung relatif masih lebih rendah dibandingkan dengan partisipasi peserta PPEM. Bahkan peserta program DPEM cenderung tidak ada yang memiliki tingkat partisipasi tinggi, dan sebaliknya peserta PPEM cenderung tidak ada yang memiliki tingkat partisipasi rendah (Tidak ada partisipasi). Sebagian peserta program DPEM yang memiliki tingkat partisipasi rendah adalah masyarakat Desa Sungai Seluang yang menerima pengguliran ternak ayam. Peserta diikutsertakan dalam kegiatan sosialisasi program yang dilaksanakan LPPM di desanya, mereka dijanjikan akan memperoleh pengguliran ternak ayam yang hasilnya nanti akan dibagi dengan LPPM melalui kontrak bagi hasil. LPPM akan memberikan bantuan dana setiap bulan untuk pakan ternak. Pada pelaksanaannya, program tidak berjalan seperti yang dijanjikan pada saat sosialisasi, pihak LPPM tidak datang secara rutin setiap bulannya dan dana bantuan untuk pakan ternak hanya diterima peserta antara dua sampai empat bulan saja.

Sebagian besar peserta program DPEM memiliki tingkat partisipasi sedang (tokenisme). Pada tingkatan ini, peserta DPEM memiliki kesempatan menyampaikan pertanyaan, ide, pendapat, atau gagasan dan menerima tanggapan atau jawaban dari pihak LPPM. Namun seringkali peserta tidak diberikan kesempatan untuk melakukan analisis kelayakan usaha bersama LPPM. Pada PPEM, sebagian besar peserta berada pada tingkat partisipasi tinggi (kekuasaan ada di masyarakat). Tim pendamping DD memberikan kesempatan yang cukup besar kepada mitranya untuk berpartisipasi. Hal ini terlihat pada kesempatan yang diberikan pendamping DD kepada masyarakat berupa kebebasan mengajukan pertanyaan, pendapat, ide atau gagasan sejak awal sosialisasi program kepada masyarakat, pembentukan KUM, dan pendampingan KUM serta kesempatan terlibat dalam kelembagaan bentukan DD, yaitu Lembaga Keuangan Mikro Syariah (LKMS) Rakat Bersama. Terdapat kurang dari setengah peserta PPEM yang memiliki tingkat partisipasi sedang (tokenisme). Pada awalnya peserta tidak menerima sosialisasi program, keikutsertaannya dalam program pun karena diajak oleh pihak lain, bukan atas dasar keinginan diri sendiri. Namun dalam perjalanannya peserta berpartisipasi dalam pengembangan usaha kelompoknya dengan turut mengelola usaha dan rutin mengikuti pendampingan yang diberikan tim pendamping DD.

\section{Hubungan Tingkat Kemauan, Kemampuan, dan Kesempatan Peserta Program dengan Tingkat Partisipasinya}

Hasil analisis Tabulasi Silang memperlihatkan kecenderungan bahwa semakin tinggi tingkat kemauan peserta program DPEM dan PPEM, semakin tinggi pula tingkat partisipasinya. Peserta PPEM dengan tingkat kemauan tinggi memiliki kecenderungan tingkat partisipasi tinggi dibandingkan peserta dengan tingkat kemauan rendah dan sedang. Terlihat bahwa tingkat kemauan peserta mampu mendorong tingkat partisipasi mereka dalam program. Namun dalam program DPEM tidak terdapat peserta yang memiliki tingkat partisipasi tinggi sehingga peserta dengan tingkat kemauan sedang dan tinggi cenderung memiliki tingkat partisipasi yang sama, yaitu sedang. Terlihat bahwa tingkat kemauan peserta program DPEM yang tinggi belum cukup mendorong partisipasi dalam program yang tinggi juga. Hasil analisis Tabulasi Silang memperlihatkan kecederungan perbedaan hubungan tingkat kemampuan dengan tingkat partisipasi pada peserta program DPEM dan PPEM. Pada program DPEM, peserta dengan tingkat kemampuan lebih rendah cenderung memiliki tingkat partisipasi yang juga lebih rendah, sedangkan pada PPEM, peserta dengan tingkat kemampuan yang lebih rendah memiliki kecenderungan tingkat partispasi yang lebih tinggi.

Hasil analisis Tabulasi Silang memperlihatkan kecenderungan bahwa semakin tinggi tingkat kesempatan peserta program DPEM dan PPEM, semakin tinggi pula tingkat partisipasinya. Peserta PPEM dalam penelitian ini seluruhnya memiliki kecenderungan tingkat kemampuan tinggi dan memiliki kecenderungan tingkat partisipasi lebih tinggi dibandingkan peserta program DPEM. Terlihat bahwa tingkat kesempatan peserta mampu mendorong mereka dalam program. Namun dalam program 
DPEM tidak terdapat peserta yang memiliki tingkat partisipasi tinggi sehingga peserta dengan tingkat kesempatan sedang dan tinggi cenderung memiliki tingkat partisipasi yang sama, yaitu sedang. Terlihat bahwa tingkat kesempatan peserta program DPEM yang tinggi belum cukup mendorong partisipasi dalam program yang tinggi juga. Namun secara keseluruhan, tingkat kesempatan peserta program DPEM dan PPEM memiliki hubungan dengan tingkat partispasinya dalam program.

Dibandingkan dengan dua faktor lainnya, yaitu tingkat kemauan dan kemampuan, tingkat kesempatan merupakan faktor yang cenderung paling memiliki hubungan dengan tingkat partisipasi peserta program. Peran pendamping dalam memberikan informasi langsung dan pendampingan kepada peserta program adalah hal yang paling dapat meningkatkan partisipasi peserta program DPEM dan PPEM. Pendampingan yang diterapkan tim pendamping DD terlihat dapat meningkatkan partisipasi pesertanya, terlihat dari persentase responden yang sebagian besar berada pada tingkat partisipasi tinggi dan sebagian lagi pada tingkat sedang.

\section{Tingkat Kemampuan Ekonomi Peserta Program}

Tingkat kemampuan ekonomi peserta PPEM relatif lebih tinggi dibandingkan dengan DPEM, atau dengan kata lain relatif lebih banyak peserta program DPEM yang tingkat kemampuan ekonominya lebih rendah dibandingkan dengan PPEM. Peserta DPEM dengan tingkat kemampuan ekonomi rendah sudah memiliki kekuasaan dalam meningkatkan kesadaran dan keinginan dirinya untuk berubah atau dengan kata lain telah memiliki evaluasi positif terhadap kontribusi ekonomi dirinya. Hal itu tercermin melalui keputusannya untuk berpartisipasi dalam program DPEM maupun PPEM untuk memperbaiki kondisi perekonomiannya. Namun mereka tidak mampu meningkatkan pengetahuan dan keterampilan dirinya, memiliki pendapatan dari usaha mandiri yang dijalankan, memiliki akses terhadap pasar, kontrol atas bantuan dana berupa pengembalian kepada LPPM, memenuhi kebutuhan konsumsi sehari-hari dan nonkonsumsi, menjadi contoh yang baik di bidang pengembangan usaha bagi masyarakat lain, serta mampu memberi gaji kepada karyawan yang membantunya mengelola usaha mandirinya.

Peserta DPEM yang memiliki tingkat kemampuan ekonomi sedang adalah masyarakat peserta program yang usahanya masih berjalan sampai saat ini. Selain peserta yang mengelola usaha kios saprodi di Desa Tamiang Bakung, peserta dengan tingkat kemampuan ekonomi sedang lainnya telah merintis usahanya sebelum mendapat bantuan dana dari LPPM, yaitu usaha kerupuk udang di Desa Papaan, ternak itik di Desa Sungai Punggawa, usaha meubel di Desa Gunung Calang, dan usaha bengkel di Desa Sekandis. KUM di Desa Tamiang Bakung telah memperoleh pendapatan dari usaha kios saprodi yang dikelolanya, KUM di Desa Papaan tidak mengalami peningkatan pendapatan dari partisipasinya dalam program
DPEM, namun KUM ini telah menjadi contoh yang baik di bidang pengembangan usaha bagi masya-rakat lainnya. KUM di Desa Sungai Punggawa meng-alami peningkatan pendapatan dan telah melunasi pinjaman dari LPPM serta mampu memenuhi kebutuhan konsumsi dan nonkonsumsi.

Peserta PPEM yang memiliki tingkat kemampuan ekonomi rendah yaitu peserta yang mengelola usaha kebun sayur di Desa Tanah Rata. Peserta tersebut berpartisipasi dalam program bukan atas dasar keinginan diri sendiri dan tidak memiliki tujuan untuk memperbaiki kondisi perekonomiannya. Mereka berpartisipasi atas ajakan rekannya untuk menjadi pionir KUM di desanya agar masyarakat lain tertarik berpartisipasi dalam PPEM dan benar saja, sejak usahanya berjalan tidak sedikit masyarakat yang mulai menunjukan ketertarikannya untuk menjalankan usaha serupa. Sebagian besar peserta PPEM memiliki tingkat kemampuan ekonomi sedang. Selain memiliki evaluasi positif terhadap kemampuan ekonomi dirinya, setelah berpartisipasi dalam PPEM, seluruh peserta mendapat pengetahuan dan keterampilan lebih yang bermanfaat untuk pengembangan usahanya. Pengetahuan dan keterampilan tersebut didapat dari pelatihan yang diadakan tim pendamping DD dan dari diskusi saat pendampingan. Selain itu beberapa peserta juga telah mampu menjadi contoh yang baik bagi masyarakat lain, memiliki atau mengalami peningkatan pendapatan dari usaha yang dikelolanya, dan sebagian telah mampu mengembalikan pinjaman dana bergulir berupa bagi hasil dengan pihak DD.

Peserta yang telah memiliki atau mengalami peningkatan pendapatan dari usaha yang dikelolanya adalah usaha kerajinan atap daun di Desa Tamiang Bakung, usaha kebun sayur di Desa Sebuli, dan usaha kios saprodi di Desa Pudi Pasar. Peserta PPEM di Desa Pudi Pasar tidak hanya sekedar memperoleh pendapatan dari usaha saprodi yang dikelola oleh empat kelompok tani setempat. Keuntungan yang didapat dari kios saprodi menurut mereka tidak seberapa, tetapi manfaat keberadaannya terasa sangat besar. Dengan adanya kios saprodi, para petani di desa tersebut merasa sangat terbantu karena kebutuhan pertanian, seperti bibit, pupuk, dan obat tidak perlu lagi mereka beli di kota karena sudah tersedia di kios tersebut. Terdapat sebagian kecil peserta PPEM yang memiliki tingkat kemampuan ekonomi tinggi. Peserta DPEM, yaitu pengelola usaha pangkalan minyak tanah di Desa Senakin Seberang, pengelola usaha warung di Desa Senakin Seberang, dan pengelola usaha keripik tempe di Desa Tebing Tinggi, sedangkan peserta PPEM adalah pengelola usaha kebun sayur dan pemotongan sapi di Desa Geronggang.

\section{Hubungan Tingkat Partisipasi Peserta Program dengan Tingkat Kemampuan Ekonominya}

Hasil analisis Tabulasi Silang memperlihatkan bahwa peserta program DPEM dengan tingkat partisipasi lebih tinggi cenderung memiliki tingkat kemampuan ekonomi 
yang lebih tinggi juga. Namun terdapat peserta yang memiliki tingkat kemampuan ekonomi tinggi sedangkan tingkat partisipasinya sedang. Terdapat beberapa hal yang diamati di lapangan yang membuat hal tersebut terjadi, diantaranya usaha yang dijalankan memang sudah maju sebelum peserta menerima bantuan dana bergulir dari program DPEM. PPEM relatif tidak menunjukkan kecenderungan karena baik partisipasi sedang maupun tinggi sama-sama memiliki tingkat kemampuan ekonomi sedang. Pada saat pengambilan data di lapangan, PPEM belum berjalan satu tahun sehingga kecenderungan tingkat kemampuan ekonomi respondennya dalam penelitian ini bukanlah dampak akhir dari program karena proses partisipasinya masih berjalan.

\section{KESIMPULAN}

Berdasarkan pembahasan mengenai faktor yang mempengaruhi partisipasi, yaitu tingkat kemauan, tingkat kemampuan, tingkat kesempatan, serta tingkat partisipasi, dan tingkat kemampuan ekonomi, maka dapat ditarik beberapa kesimpulan sebagai berikut:

1. tingkat kemauan peserta program DPEM dan PPEM relatif tinggi, artinya keinginan peserta program untuk berpartisipasi dalam program pemberdayaan ekonomi tinggi. Tingkat kemampuan peserta PPEM relatif lebih rendah dibandingkan peserta program DPEM. Tingkat kesempatan peserta program DPEM cenderung lebih rendah dibandingkan peserta PPEM;

2. tingkat partisipasi peserta program DPEM relatif masih lebih rendah dibandingkan dengan partisipasi peserta PPEM bahkan peserta program DPEM tidak ada yang memiliki tingkat partisipasi tinggi, dan sebaliknya peserta PPEM tidak ada yang memiliki tingkat partisipasi rendah;

3. berdasarkan hasil Tabulasi Silang antara tingkat kemauan, tingkat kemampuan, dan kesempatan dengan tingkat partisipasi, dapat disimpulkan bahwa pada program DPEM, terdapat hubungan antara tingkat kemampuan dan kesempatan peserta program dengan tingkat partisipasinya, namun tidak terdapat hubungan antara tingkat kemauan peserta program dengan tingkat partisipasinya. Pada PPEM, terdapat hubungan antara tingkat kemauan dan kesempatan peserta program dengan tingkat partisipasinya, namun tidak terdapat hubungan antara tingkat kemampuan peserta program dengan tingkat partisipasinya. Dari tiga faktor yang mendukung terciptanya partisipasi, tingkat kesempatan merupakan faktor yang cenderung memiliki hubungan kuat dengan tingkat partisipasi. Tingkat keterdedahan informasi dan tingkat pendampingan yang tinggi cenderung meningkatkan partisipasi peserta program DPEM dan PPEM;

4. tingkat kemampuan ekonomi peserta PPEM relatif lebih tinggi dibandingkan dengan DPEM, atau dengan kata lain relatif lebih banyak peserta program DPEM yang tingkat kemampuan ekonominya lebih rendah dibandingkan dengan PPEM. Berdasarkan hasil
Tabulasi Silang antara tingkat partisipasi dan tingkat kemampuan ekonomi dapat disimpulkan bahwa terdapat hubungan antara tingkat partisipasi peserta program DPEM dengan tingkat kemampuan ekonominya, dan tidak terdapat hubungan antara tingkat partisipasi peserta PPEM dengan tingkat kemampuan ekonominya dalam kurun satu tahun pelaksanaannya, hal ini dapat berubah karena PPEM masih berjalan.

\section{SARAN}

Merujuk kepada tujuan penelitian dan hasil penelitian, maka Community Department, LPPM, dan tim pendamping Dompet Dhufa Republika perlu mempertimbangkan hal-hal sebagai berikut:

1. berdasarkan hasil penelitian, tingkat kemauan peserta program DPEM dan PPEM relatif tinggi yang mengindikasikan besarnya harapan peserta akan manfaat yang akan diterimanya dari program. Oleh karena itu, kedepannya diharapkan kedua program mampu menjawab harapan-harapan tersebut. Khususnya program DPEM, yaitu dengan mengadakan pelatihan dalam rangka peningkatan kapasitas peserta programnya. Tingkat kemampuan peserta PPEM cenderung lebih rendah dibandingkan program DPEM. Hal ini mengindikasikan rendahnya pengalaman peserta PPEM disebabkan jenis usaha yang dikembangkan tergolong baru bagi peserta, seperti ternak sapi, kebun sayur dan penanaman padi bibit unggul. Oleh karena itu, tim pendamping DD diharapkan dapat lebih meningkatkan pengetahuan dan keterampilan peserta program yang belum memiliki pengalaman di bidang usaha yang baru digelutinya itu. Tingkat kesempatan peserta program DPEM cenderung lebih rendah dibandingkan PPEM. Hal ini mengindikasikan rendahnya pendampingan LPPM kepada peserta program. Harapannya, LPPM dapat lebih memperbaiki pola pendampingan dengan meningkatkan kualitas dan kuantitas pendamping, membuat jadwal kunjungan rutin, mengadakan diskusi kelompok terarah (FGD) dengan para peserta program seputar masalah dan kendala yang dihadapi, memberikan pelatihan seputar yang bermanfaat untuk pengembangan usaha dalam rangka memberdayakan dan memandirikan peserta pasca pemberian bantuan dana bergulir. Selain itu, LPPM juga perlu untuk mengenalkan kembali program DPEM kepada masyarakat melalui sosialisasi secara langsung atau melalui aparat desa di setiap desa binaan dalam rangka meningkatkan keterdedahan informasi masyarakat akan program DPEM;

2. LPPM diharapkan dapat meningkatkan partisipasi peserta program DPEM dengan memberikan ruang lebih dan mendorong partisipasi aktif peserta program melalui meningkatkan komunikasi dua arah antara perusahaan atau LPPM dengan peserta program. Selain itu, Community Department perlu memetakan kembali sasaran program DPEM dan PPEM agar 
masyarakat sekitar tambang menerima program pemberdayaan ekonomi secara merata dan tepat sasaran. Tim pendamping LPPM dan DD diharapkan dapat saling belajar satu sama lain mengenai teknis pendampingan masyarakat di lapangan. Community Department bersama LPPM perlu merumuskan kembali rencana kerja program DPEM seperti yang telah diterapkan oleh tim pendamping DD. Mengoptimalkan peran perusahaan, seperti membantu mengenalkan pasar yang potensial kepada peserta program untuk memasarkan hasil usahanya;

3. tingkat kesempatan cenderung memiliki hubungan yang paling kuat dengan tingkat partisipasi peserta program. Harapannya, tim pendamping LPPM dan DD dapat lebih meningkatkan tingkat keterdedahan informasi dan pendampingan kepada peserta program.

Tim pendamping DD dan LPPM perlu meningkatkan partisipasi peserta program karena tingkat partisipasi peserta program cenderung memiliki hubungan dengan tingkat kemampuan ekonominya. Tim pendamping juga perlu menyusun kembali indikator keberhasilan program yang terukur dan sesuai dengan tujuan awal program, yaitu memperbaiki kondisi perekonomian peserta program.

\section{DAFTAR PUSTAKA}

Ambadar, Jackie. 2008. Corporate social responsibility (CSR) dalam Praktik di Indonesia. Wujud Kepedulian Dunia Usaha. Jakarta: PT Elex Media Komputindo.

Apandi, Arif. 2010. Tingkat Partisipasi Masyarakat dalam Program Pemberdayaan Ekonomi "Aku Himung Petani Banua" dari Perspektif Kapital Sosial. Skripsi. Departemen Sains Komunikasi dan Pengembangan Masyarakat. Institut Pertanian Bogor.

Budimanta, Arif et al. 2008. Corporate Social Responsbility: Alternatif Bagi Pembangunan di Indonesia. Jakarta: Indonesia Center for Suistainable Development.

Chusnah, U. 2008. Evaluasi Partisipasi Masyarakat Dalam pelaksanaan Program Peningkatan Kualitas Sarana Prasarana Pendidikan Di SMA Negeri 1 Surakarta. Tesis. Program Pascasarjana. Universitas Diponegoro Semarang.

Dompet Dhuafa Republika. 2011. Laporan Triwulan 3 Program Pemberdayaan Ekonomi Masyarakat Sekitar Pertambangan Senakin. Tidak Diterbitkan. PT Arutmin Indonesia Tambang Senakin dan Dompet Dhuafa Republika.

Ife, Jim. 1995. Community Development: Creating Community Alternatives Vision, Analysis and Practice. Melbourne: Longman.
Lugiarti, Eppy. 2004. Peningkatan Partisipasi Masyarakat dalam Proses Perencanaan Program Pengembangan Masyarakat di Komunitas Desa Cijayanti. Tesis. Sekolah Pascasarjana. Institut Pertanian Bogor.

Makmur, Setia. 2005. Partisipasi Masyarakat Dalam Program Pengembangan Prasarana Perdesaan (P2D). Skripsi. Departemen Ilmu-ilmu Sosial Ekonomi Pertanian Fakultas Pertanian. Institut Pertanian Bogor.

Nasdian, F. Tonny. 2006. Modul Kuliah Pengembangan Masyarakat. Tidak Diterbitkan. Institut Pertanian Bogor.

Singarimbun, Masri dan Sofian Effendi (ed.). 1989. Metode Penelitian Survei. Jakarta: LP3ES.

Slamet, Margono. 2003. Membentuk Pola Perilaku Manusia Pembangunan. Bogor: IPB Press.

Suharto, Edi. 2005. Membangun Masyarakat Memberdayakan Rakyat. Bandung: PT Refika Aditama.

Sukada, Sonny, dkk. 2007. Membumikan Bisnis Berkelanjutan. Memahami Konsep dan Praktik Tanggung Jawab Sosial Perusahaan. Jakarta: Indonesia Business Links.

Tasbichah, Ummi. 2011. Hubungan Kapital Sosial dengan Tingkat Partisipasi Santri dalam Program Pertanian Pesantren. Skripsi. Departemen Sains Komunikasi dan Pengembangan Masyarakat. Institut Pertanian Bogor.

Wahyuni, Eka S. 2010. Pedoman Teknik Penulisan Laporan Studi Pustaka. Tidak Diterbitkan. Institut Pertanian Bogor.

Wibisono, Yusuf. 2007. Membedah Konsep dan Aplikasi CSR (Corporate Social Responsibility). Gresik: Fascho Publishing.

\section{Lampiran}

Lampiran 1. Peta Desa Binaan PT Arutmin Indonesia Tambang Senakin

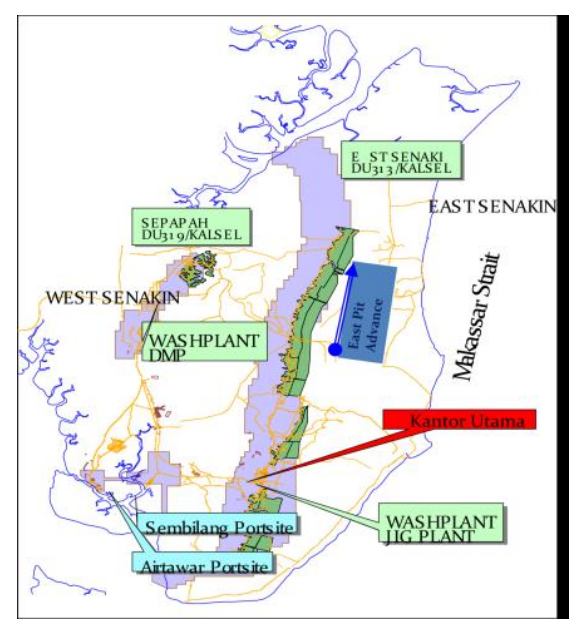


